\title{
On the Father-Son Confrontation in Henderson the Rain King
}

\author{
Aoshuang Yang \\ School of Foreign Languages \& Cultures, Sichuan University, Chengdu 610065, China. \\ yiyou0707@163.com
}

\begin{abstract}
Henderson the Rain King which tells the story of a WASP millionaire called Eugene Henderson is one of Saul Bellow's best-known works. This paper will have its focus on the fatherson relationship, or more precisely, the father-son confrontation, which is a significant clue to comprehend the major theme of the novel: the spiritual poverty in material sufficiency. Consisting of six parts, the paper will firstly have a brief introduction of the writer and the book. Then it will discuss the archetype of the father-son confrontation, how they confront each other, the reasons for their confrontation, and their reconciliation. In the end, a conclusion will be involved.
\end{abstract}

Keywords: Father-son confrontation, archetype, spiritual poverty, material affluence.

\section{Introduction}

As one of Saul Bellow's best-known works, Henderson the Rain King occupies an extremely important position in the letters, being a classic example of the new type of picaresque novel. In 1959, "Bellow published perhaps his most daring novel, Henderson the Rain King which was set in a purely imagined Africa (Bellow never visited that continent) and starred Henderson, one of Bellow's most unforgettable and irrepressible heroes" (Boswell 29). Though there are dozens of articles and booklength studies concerned with this novel due to its greatness and significance, few explore the fatherson relationship in the novel. While this paper will have its focus on the father-son relationship, and tries to explore how this kind of relationship affects the protagonist's psychology and drives him to fulfill his spiritual journey.

\section{Archetype of the Father-Son Confrontation}

Generally speaking, there are three sources related to the archetype of the father-son confrontation in western culture, namely, the Bible, the Greek mythology, and the Oedipus complex illustrated by Freud. (Liu Hongyi 100-112) According to the Bible, Adam and Eve violate God's will by eating the fruit of the Tree of Knowledge. To punish them, God drives the couple out from the Garden of Eden and deprives the immortality of their lives. Therefore, human beings, represented by their ancestors Adam and Eve, from the very beginning of their creation are set against their creator or Father whose another name is God. Besides, in Greek mythology, the father-son confrontation is mainly involved in the contest for the absolute power as the sole ruler. When Uranus became the king of the gods, in case that he might be overturned by his offspring one day, he threw all his sons and daughters into the abyss. Even though, his reign was overthrown by his son Cronos. To avoid the same threats, Cronos devoured his children. However, he was overthrown by his son Zeus, too. The third origin of the archetype of the father-son confrontation comes from the famous Freudian theory. According to Freud, sons, who are born with an obsession with their mother, are inclined to regard their father as an enemy and challenge him. Then, it is inevitable that fathers and sons are trapped in some kind of confrontation from the very start.

\section{The Confrontation between Father and Son in the Novel}

Henderson the Rain King tells a story of a WASP millionaire called Eugene Henderson. In this novel, the father-son relationship becomes an important clue to understand the profound meaning underneath the story. As a matter of fact, there are mainly three father-son relationships throughout the novel, namely, Henderson and his father, Dick and his father, Edward (son) and Henderson (father). While the foremost one lies in the protagonist Henderson and his father. From the beginning 
of the story to almost the end, Henderson and his father are in a severe confrontation. For Henderson, his elder brother Dick is his father's favorite. After the accidental death of Dick, his father is lost in deep grief. And this kind of grief transforms into anger and is projected upon Henderson. It deeply hurts him for "the old man...made me feel our family line had ended up with Dick up in the Adiroudacks" (Bellow 305). Thus he behaves rebelliously since then by leaving home, working at a place about three miles away. He even goes to work on the day of Dick's funeral, which enrages his father. "Fiercely, the old man started to yell at me" (Bellow 306). "My father in his grief swore at me...He cursed..." (Bellow 306) "It took all my father's charity to forgive me and I don't think he ever made it together" (Bellow 2).

\section{Reasons for the Father-Son Confrontation}

It's not difficult to see that Henderson and his father are at war from the first pages of the book. Certainly, there are some explanations for such kind of confrontation between the son and the father. On the surface, Henderson's hatred for his father comes from his father's neglection of him. However, in a higher sense, the father-son confrontation is resulted from the incompatibility between material abundance and spiritual poverty, between the suffocating force of modern civilization and the quest for achieving selfhood and individual values.

First of all, on the superficial level, Henderson's father is partial to his brother, which deeply hurts Henderson's feelings and makes negative impacts to the son's growth. Actually, Henderson feels affectionate for his father. In order to please he, Henderson gets married with a girl of their social class, not one he loves. After the death of his father, Henderson tries to play violin, an instrument his father used to play, to reach him. "I had felt I was pursuing my father's spirit...I played with dedication, with feeling, with longing, with love_play to the point of collapse" (Bellow 26). What's more, readers may notice that Henderson always tends to show a tender heart to children. For instance, in the end of the novel, Henderson takes care of an orphan who bears great similarity with Henderson himself. At first, the two resemble in appearance. "He was very white...He was a black-haired boy, like my own. This kid went to my heart" (Bellow 304-305). In addition to the similar appearance, they share a similar fate. The kid's parents' death becomes a disguised form of abandonment, which is essentially equal to Henderson's isolation from his father. Henderson projects his desperate yearning for love from his father upon the kid by looking after him. Besides, his cherishing of the old bear can be another example. The man and the animal treasure each other because of the same fatebeing abandoned. "By a common bond of despair we embraced." "We're two of a kind, Smolak (the name of the bear) was cast off and I am an Ishmael, too" (Bellow 307). Despite of the deep affection Henderson harbors for his father, "he was despised and rejected" (Bellow 26). Especially when Dick, the favorite of his father, dies, his father looks at him and despairs, and his face makes Henderson feel their family line has ended up with Dick. All those turn to be the negative elements through Henderson's psychological growth, and eventually become a factor responsible for his spiritual emptiness.

After the death of Dick and his father, Henderson "inherited three million dollars after taxes" (Bellow 1). However, the tremendous wealth brings Henderson everything but happiness. He feels burdensome because the wealth originally belongs not to him but to his brother. This sense of guilt always makes him feel as a displaced person. "I filled a place in existence which should be filled properly by someone else" (Bellow 170). "There are mostly people who feel that they occupy the place that belongs to another by rights. There are displaced persons everywhere" (Bellow 30). This sense of guilt and displacement intensifies the crisis of his spiritual emptiness. So the confrontation between Henderson and his father means not merely the contradiction between the physical father and son connected by blood but the contradiction between material richness and spiritual emptiness. Representing the material abundance of the modern civilization, Henderson's father restrains his son's selfhood. Under this kind of suppression, the values of Henderson as an individual existence cannot be realized and recognized. Before his trip to Africa, Henderson has been tortured by an inner 
voice sounded as "I want, I want". He doesn't know what exactly he wants. Actually, one thing he really wants is the realization of his selfhood and values as an individual.

In addition to the money and family background, the physically strong body endowed by his father provides another account for Henderson's hatred to him. With six inches' height and 230 pounds, Henderson inherits a strong and tough body from his father. Whereas, his "strength isn't happy strength" because of the fact that human body which is made of flesh and bones are mortal, being threatened by death anytime (Bellow 62). It directly causes Henderson's fear over death. Henderson sighs that "it's miserable to be human. You get such queer diseases. Just because you're human and for no other reason" (Bellow 75). Henderson embarrasses Lily before their gusts deliberately because he heard Lily say he's strong and unkillable on the phone. In fact, Lily said this jokingly. Nonetheless, Henderson is so sensitive that he "put an antagonistic interpretation on it" (Bellow 4). The word "unkillable" reminds him of death. Throughout the novel, Henderson complains several times that he is always encircled by death. And it is the death of the old lady on his floor that precipitates him to take measures. Therefore, his desire to be relieved from the anxiety over death becomes the second thing he wants.

\section{The Reconciliation of the Father-Son Confrontation}

Owing to his desire to get rid of the suffocating force of modern civilization, to recover his selfhood, to realize his individual values, and to overcome his fear for death, Henderson starts his journey to Africa. And the primitive region which represents the simplified past does not disappoint him. In the imagined Africa created by Saul Bellow, Henderson visits two primitive tribes, the Arnewi and the Wariri, in which Henderson successfully realizes his fundamental values and recovers his selfhood. In Africa, his dollars and family background are meaningless. Here, one can only be admitted through his own efforts and ability. In the Arnewi, Henderson wins over Prince Itelo in the wrestle, relying on his own strength. Itelo cries, "Oh, Mistah Henderson! Henderson, I know you now. Oh, sir, I know you now" (Bellow 62). Here Henderson is admitted and accepted by Itelo completely because of his personal capacity. Now, for the first time, his strong body becomes useful. Instead of being the reminder of the threat from death, his strength turns to be a tool which helps him prove himself. When Henderson is informed that the Arnewi people and their cattle are suffering from the frogs in the water, he is eager to relieve them. Obviously, his enthusiasm stems from his urgent demands to prove his worth. Whereas, he fails to accomplish the mission. His usage of the home-made bomb whose materials and manufacturing techniques come from the civilized world is doomed to failure. After the failure in the Arnewi, Henderson and his primitive guide enter into the Wariri, where he hoists up the goddess Mummah and becomes the rain king. It is the most significant step for Henderson to realize his values. He moves Mummah and brings water to the tribe. In this novel, water is one of the most important symbols. When referred to for the first time, water is the essential power for the blooming of the flowers in the desert. Besides, before his trip to Africa, Henderson has being aware of the significance of water. When is at war with his father at the time of Dick's death, he flies way from home to Niagara Falls, where he is "entranced by the crash of the water." "Water can be healing" (Bellow 306). Here, water transforms into a medicine which cures the wound of his heart. Therefore, water symbolizes life and some sort of healing power. In bringing rain to the Wariri people who are suffering from drought, Henderson brings them the vitality of life and hope. Thus, from a negligible figure living behind the shadow of the prestigious family to a requisite one who brings life vitality and hope to others, Henderson eventually fulfills his aspiration to realize his fundamental value as an individual existence. That explains why, after lifting up Mummah, Henderson "was so gladdened by what I had done that my whole body is filled with soft heat, with soft and sacred light...My spirit was awake, and it welcomed life anew. Damn the whole as awake, and it welcomed life anew.damn nd sacred light.rs, Henderson eventually fulfills his aopiration ain, lifts hthing! Life anew!'(Bellow 173)

In addition, the second thing Henderson wants is to get rid of the fear for death. In the Arnewi, the old queen tells him "Grun-tu-molani" which means "you want to live" (Bellow 76). But Dahfu, the king of the Wariri, tells him, "Granted, Grun-tu-molani is much, but it is not alone sufficient. Mr. 
Henderson, more is required" (Bellow 196). Thereafter, Dahfu guides him the journey to overcome his fear over death by the straightforward confronting with and imitating the lioness under the palace. Before he enters the interior Africa, Henderson acts an avoider by drinking and causing troubles for his neighbors. From the lioness and Dahfu, Henderson learns to face up the fear over death eventually. More precisely, Henderson's fear over death is actually his fear over confronting reality. What's essential to the confrontation between Henderson and his father lies in the fact that the material abundance of modern civilization represented by his father suffocates his selfhood and worth as individual existence. The way Henderson fights against it is more of avoiding or escaping than of taking substantive measures. However, after the trip to Africa, with what has learned from Dahfu and the lioness, Henderson is determined to fulfill his dream - to a doctor, which means he is now able to make efforts to achieve his self-values in the same world that depressed him so much without considering the wealth he inherited. What's more, he recollects the love of his father for him. "I suppose my dad wished. That I had gotten drowned instead of my brother Dick...Did this mean he didn't love me? Not at all. I, too, being a son, it tormented the old guy to wish it. Yes, if it had been me instead, he would have wept almost as much. He loved both his sons" (Bellow 288). Besides, now Henderson also understands the grief and anger of his father when Dick was drowned, which he "couldn't see it at sixteen" "An old man, disappointed, of failing strength, may try to reinvigorate himself by means of anger" (Bellow 306). All of what has been discussed above illustrates that Henderson has gained the courage to face up the reality, signifying his reconciliation with his father. And it is symbolized by the orphan on the plane in the end of the novel. Henderson feels the kid's "two smoothly gray eyes" moving at him, which "greatly expanded into the whites - new to life together. They had that new luster" (Bellow 308).

\section{Conclusion}

Most critics share the idea that Henderson the Rain King tells about the "spiritual emptiness in the midst of sufficiency: a poverty of the soul as terrible as material itself" (Kyung-Ae Kim 85). The confrontation between the protagonist and his father becomes a significant clue to present this theme. On the surface, the war between the son and the father is resulted from the father's neglection of the son and partiality to his brother. However, the essential reasons why Henderson hates his father that much come from the heritage he gained from his father-money, family background, and body. Money and family background which represent the material abundance of modern civilization suffocate Henderson's selfhood and obliterate his values as an individual existence. And the strong body which is mortal always reminds him of death. In this sense, the confrontation between Henderson and his father is upgraded to the confrontation between material sufficiency and spiritual poverty, between the suffocating force of modern civilization and the quest for the achievement of selfhood and individual values. To pursue salvation, Henderson makes a journey to the interior Africa where is far from modern civilization. In the primitive tribes, Henderson recovers his selfhood, realizes his fundamental values, overcomes the fear over death, and learns to face up the reality, signifying his final reconciliation with his father.

\section{References}

[1]. Bellow, Saul. Henderson the Rain King. New York: The Viking Press, 1959. Print.

[2]. Boswell, Marshall. "Bellow, Saul." Encyclopedia of American Literature (Revised Edition). Ed. Marshall Boswell and Carl Rollyson. Vol. 4. Shanghai: Shanghai Foreign Language Education Press, 2011. Print.

[3]. Fiedler, Leslie A. "Saul Bellow." Contemporary Literary Criticism. Ed. Carolyn Riley. Vol. 1. Detroit: Gale, 1991. Print.

[4]. Kim, Kyung-Age. Quest for Salvation in Saul Bellow's Novels. Frankfurt: Peter Lang, 1994. Print.

[5]. Liu Honie. Toward Cultural Poetics, Beijing: Peking University Press, 2002.11. 